\title{
THE POPULARITY OF WARANGGANA TAYUB MALANG THROUGH BODY EXPLOITATION
}

\author{
Robby Hidajat \\ Faculty of Letters of Malang State University, Indonesia \\ ${ }^{\square}$ Jl. Semarang 5, Jawa Timur 65145, Indonesia \\ E-mail: gantargumelar@gmail.com
}

Received: July 3, 2014. Revised: August 14, 2014. Accepted: November 22, 2014

\begin{abstract}
Tayub is a Ronggeng type of dance performance. It is widely performed in Javanese regions. Originally, Tayub functioned as a fertility ritual; then it developed as entertainment. The growth of Tayub in Malang in the 1950s was intended for identity and the main dancer called Tandak was changed to Waranggana. As a result, there was a transformation in the form of the dancer's body: (1) exploring body-initiating identity, (2) manipulating the body through magical effect, and (3) body consumptive economization and love ruse. The qualitative method was used with an art phenomenological model in this study. The data were collected using interview and observation methods and was analyzed interpretatively. The result of the research was that female body interpretation is politicized to survive creatively, in order to maintain popularity and to support the lifestyle of the artist.
\end{abstract}

Keywords: body; creativity; exploitation; mask dance; waranggana

How to Cite: Hidajat, R. (2015). The Popularity of Waranggana Tayub Malang through Body Exploitation. Harmonia: Journal of Arts Research and Education, 14(2), 72-77. doi:http:/ / dx.doi.org/10.15294/harmonia.v14i2.3288

\section{INTRODUCTION}

Professional dancers always have problems in their appearance, body, face, and dancing skill that can constantly fascinate their audiences. Tayub Malang puts the women (dancers) into primary characters. In the Malang area of East Java, a Tayub dancer is called Waranggana. Nancy (2009, p. 609) call the dancer as a glamorous women singer who appear ordinary in their everyday lives, but become exemplars of extraordinary femininity in performances where flirtatious interactions may occur between them and male musicians. Futhermore, the research states that through singing and silences, Waranggana preserve men's prestige and together with them participate in a social construction that usually keeps the peace at local levels.
In Blora regency, Indonesia, the dancer of Tayub is called Ledek (Ratih, 2005, p. 42).

Originally, Tayub functioned to cheer the grand harvest party and to respect the King (Holt, 2000). It was held on the edge of the farm. The dancer who danced (ngibing) first along with the Ledhek was the village elders. Such an event was called Bedah bumi (earth sectioning), the symbol of sexual relationship between Pengibing (ordinary people who dance) and the Ledhek. The sympathetic magical power of the symbol of "women impregnation" affected the farm soil fertility, so that Tayub party is called fertility ritual (Suharto, 1999). Nancy's research (2000, p. 607) shows that these "seduction scenarios" are ways in which women, through their attractive power, help men transform their exuberant power into constructive spiritual potency. 
More superficially, men use these seduction scenarios to position themselves in a masculine prestige hierarchy.

Geertz perceives Tayub as an entertainment in which the Waranggana body spoils many men's eyes. Such the accusation is addressed to the Waranggana who sings erotic song lyric, with passionate dancing, thereby making the wives jealous. Many Waranggana's had love affairs with other's husbands. The woman as a Waranggana was accused of being a "prostitute". Women organization in the 1960s, Perwari (priyayi women's association) disliked and resisted the Tayub performance (Geertz, 2013).

The Tayub association needed a dancer who can perform excellently with varied dancing movement, sweet voice, slim bright body, and beautiful face. Such these ideal criteria were difficult to meet with the women who had continuously chosen $\mathrm{Wa}$ ranggana as their profession. A variety of strategies were taken to make the Waranggana remain to be acceptable to the Tayub devotees. Waranggana grows over the years. Originally Tayub summoners presented only 2-3 Waranggana's, but in 2000s, they presented at least 508 dances. Considering the Waranggana growth in Malang becomes an interesting study. On the one hand, the society dislikes because they are worried that their husbands will be fascinated by the Waranggana's. On the other hand, the number of women performing persistently the wrong profession was increased. The prospect Waranggana's were available to learn from the senior Waranggana for many years. In a research, Cahyono (2006, p. 19) shows that the inheritance pattern of Tayub, where they sing and dance, is done traditionally and naturally. In their community, they do this inheritance pattern through learning by doing.

This study aimed to learn the strategy to make a Waranggana remaining to be favoured by the society. The problems formulated are (1) What strategies are used to make the Waranggana popular? And (2) Why is that strategy taken by the Waranggana to be popular?

\section{METHODS}

This study employed qualitative approach, interpreting the data constituting the performer's actions and words explored directly from the object. The data were collected using an interview and observation techniques. The model of research used was art phenomenology using developmental theory. The key informants in Karawitan Tayub area were Sumantri (57 years), an artist of Karawitan Tayub who has been performing this art in 1950s, and Ruminingsih (60 years), a Waranggana and daughter of Tayub drummer from Jatiguwi. Data analysis employed descriptive interpretative technique.

\section{Data Collection}

Originally, Tayub functioned as a means of a fertility rite, and then it developed as entertainment. Tayub performance as entertainment still develops until today, particularly in the Javanese north coastal area. The presentation has been collaborated with joged dangdut (dangdut dance) movement element. In Malang Regency of East Java, Tayub performance has been known since 1920s. Generally, Tayub had Central Java style. In 1950s, typical Malang Tayub began to be explored in order to be different from Central Java's Tayub.

Toward the end of 1960s, some Tandhak (another name for Waranggana) wanted to raise local characteristic as their identity, because so far the Tayub style developing in Malang was Central Java style. If observed closely, the Malang-origin Tandhaks' effort seemed to be disturbed in by many other Tandhaks from Kediri, Blitar, and Tulungagung came to Malang.

\section{RESULTS AND DISCUSSION}

\section{Exploring Body-Initiating Identity}

A Tandhak named Miskanah from Gadang Village initiated the innovation in Gambyong Dance (Central Java-style dance) appearance performed by Malang Tandak replaced with Tari Remo (Remo Dance). 
Miskanah was used to be a Bedayan dancer in Kethoprak and Remo dance in Ludruk. Her effort was successful so that the Tandhaks coming from out of Malang area cannot copy Maskinah's appearance.

At the end of 1970s, Miskanah style dance had been popular among the Tayub devotees. The Miskanah dancing style was more dynamic, muscular, and energetic. The masculine movement pattern of Remo dance was modified with Pencak Silat (self-defense art) pattern. Because the performer was a female, her choreography felt to be aggressive, and her step and arm movement was always accompanied by a Malang drum pattern and sometimes at the end of the movement an emphasis was given to intense Jidor Pencak sound (Sumantri, interview on June 3, 2011).

Entering 1970s, Tayub Malang performing art organization attempted to change the morality image of the past Tandhak by popularizing the term Waranggana. This term derived from a predicate presenter in Karawitan or leather puppet ensemble. The term Waranggana for Tayub dancer felt to be elegant and had Javanese-bourgeois image. Waranggana's fashion originally wearing Angkin cloth as Kemben was changed into javanese Kebayak. Waranggana's appearance seemed to be more elegant. This attempt is considered as a smart way, a political strategy of interpreting body to maintain Tayub appearance among its devotees. Waranggana at least got a more respected social position.

In 1950s Tandhak was often despised in front of the public by her devotees. Sumantri (67 years) witnessed sexual abuses the Tandhaks experienced. Such unpleasant condition generally did not result in resistant reaction to that treatment. That treatment seemed to be ordinary. Generally, the devotees who were dare to do so have much money. At that time Suwelan (put the tips into the dancer's Kemben become a common habit (Sumantri, interview on June 3, 2011).

After the development of a Miskanah style of Remo Tayub dance that was dynamic and energetic, the Tayub devotees' behavior changed. This change was at least because the Waranggana's more masculine appearance. Cakraningrat style of Remo dance's fashion was modified by adding a small vest, higher sembong jarit, inserting cundrik (dagger for women) on the left side. Male-style makeup with a thin mustache, hair bonded with Udeng Kemplengan (Headben) ala Madura young man was used (Suprihatin, 1997).

In 1980s, the development of Tayub Malang was increasingly popular. Its Waranggana's appearance and dancing showed the true Malang characteristic. Such the peculiarity became the obstacle for the Central Java style of Tayub dancer Tayub Malang dancer generation who carried such the typical style flourished in the beginning of 1970s. Entering 1980s, Tayub dancers from Malang flourished. Tayub summoners no longer presented 2 or 3 but 5-8 Waranggana's to cheer their party. The senior dancer performed RemoTayub with "Tembelan" attraction performance.

The development of Remo Tayub Malang dance included Silat (self-defense art) into its structure. The objective was to build an aggressive and dynamic characteristic; but in its development, the Silat movement appeared only as accentuation, with strong and opened hand movement. In young Waranggana's hand, the Silat element was faded by jogged ndangdut and jaipongan (Sundanese music) movements, particularly in Tembelan act. Attraction of giving tips was done by attaching the money onto the dance body. The objective was to be capable of dancing with Gendhings (Javanese music) chosen by Pengibing (javanese dancer). This Tembelan attraction occurred in the opening, Nembel Tandhak Remo dancer. The Tembelan phenomenon developed around 1980-1990 popularized by such Waranggana'sas Sri Utami, Hani, Rumaningsih, Yayuk, Sri Mani, and other young Waranggana's (Rumaningsih, July 12, 2011).

The 'timberline' attraction has an artistic effect of Tayub dance. However, viewed from the devotees, this phenomenon made it difficult for them to get involved 
in Tayub environment. It should be taken into account and rethought. They should spend much money for attending one performance. A devotee should spend money for contribution to the host of the event (buwuh), playing song, tips for Waranggana (the money was distributed evenly for all Waranggana on the stage), and Tembelan tips. Therefore, surely the Tayub devotees should not only blater (supple) but also have much money, and high position.

\section{Body Manipulation through Magical Ef- fect}

The use of term Pelandang serving as Master of Ceremony (MC) was considered as having image less equal to the term $W a-$ ranggana, so the term pramugari was used. This term was considered as more exclusive recalling that pramugari (stewardess) is the women who served the plane passengers. But some people attempted to use the term considered as more refined, pranata beksa (choreographer), meaning those serving to organize the ones dancing: Waranggana and Pengibing. At that time, the term Pengibing was not changed. Tayub devotees did not need image because they were those who have a position and money. So there was no designation for their prestige. They would be apparently strong when their wallet is thick.

Such the condition became a heavy challenge, particularly in the competition to get attention and the attempt of maintaining self-image, despite the change of their profession designation. They no longer get discretion to show their erotic attraction off on the stage. The name Waranggana is required to improve the quality of performance, particularly her vocal quality. Meanwhile, the change of term pelandang into pramugari did not bring about burden. The pelandang still has discretion to organize those who enter kalangan (stage). Despite the common etiquette still prevailing, the first sampur (sash) will fall down to the host of event, and then to local functionaries such as Lurah (chief of village) or Camat (chief of sub-district). There after it will fall down to the devotees. The condi- tion of Waranggana's' improved self-image weakened their mentality. Over time they looked for protection and maintained the market image in order to get sympathy from their devotees.

Young Waranggana's were less established viewed from their vocal technical quality and dancing basic skill. Some of them often used shaman, as a shortcut, to manipulate their body by installing susuk (implant). Particular metal with a half of needle size is implanted into the middle of the brow, the encounter between the two eyebrows, cheek, or the tip of lips. The use of beauty implant is no longer a secret. Individual Waranggana's exchange information each other about the efficacy of implant installer. The lovely, beautiful and shining face is the strategy of attracting the devotees. Some of Tandhaks who have strong bravery come to a holy place (graves of ancestors) to ask for magic power called Stren. This magical effect made the Waranggana performing beyond her potential. $W a-$ ranggana Stren has certain abstinence and is available to provide tumbal (something used to prevent misfortune) (Sumantri, interview on August 5, 2011). This shortcut is taken because of the Waranggana's' very low education level, generally elementary school. Until 1990s, only one Waranggana studied at Junior High School (SMP), Rumaningsih.

\section{Body Economization and Love Ruse}

1990s was the golden age for Tayub Malang development. The Tayub presentation activity was not only due to the host of the event's request. But, it had been organized in such a way that all devotees got the opportunity of holding Tayub presentation consecutively. This system was called Arisan. The presentation list has been arranged for a year (it stopped for a while in Ramadhan month). During Ramadhan month, it stopped from performing for a month. Such condition became a distinctive problem to the Waranggana. It ceased their income. Meanwhile, they had no alternative skill to earn their life. Most of Waranggana's were village females 
with agrarian background. When they became Waranggana, they stopped from doing activities as the farmers. They also rarely socialized with their neighbors. Such condition forced the Waranggana to look for self-salvaging strategy. The Waranggana's, whose main income from their husbands was not high, took shortcut by the opportunity of throwing the love ruse out to local functionaries such as Lurah (chief of the village), Camat (chief of sub-district) and a rich merchant. This conventional strategy was like what Geertz reported in 1960s (Geertz, 2013).

The strategy of throwing the love ruse out was not vulgar and without background. Waranggana's who were able to throw the love ruse out had appearance potentials, including fascinating body, beautiful face and sensitive-emotionalcommunicative kinesthetic. Thus, the physical symbols can conquer all men's heart. The politicization for body consumptive economisation aimed to make the devotees feeling the need for consuming the dancer's body. Waranggana's could make their devotees happy, imagining, and feeling as if they were dancing with the fairies. This sensation is a social ecstasy. Such imaginary impression would not really be felt unless it is followed by liquor. The economic role of the liquor seller also contributed to Strengthening the Waranggana's' strategy.

The effect of love ruse resulted in the marriage-divorce phenomenon. It was strongly assumed that such phenomenon resulted from the Waranggana's' need for supporting their lifestyle as artists (Suwito, interview on August 15, 2011). Suwito's information was also reported by Raffles in The History of Java. The Ronggengs decided to divorce and have a new husband. Having lived peacefully for some time in the village, they might decide to divorce and to get back into their original profession as Ronggeng (Raffles, 2008).

For the Waranggana's who had been established economically, despite their status as the second wife, they focused on solidifying their status and they wanted to keep enjoying their world development. Some of them became dancing and vocal instructors, and some others became dukun susuk (medicaster).

\section{CONCLUSION}

The result of research on Tayub Malang during 1950-1990 showed that the original period in 1950 was called as the era of searching identity and creativity, 1960s as the growth and the popularity era of Tayub Malang, and 1980s as (women) body consumptive commercialization politicized to survive in the terms of creativity, popularity and to support lifestyle as an artist.

However, it is undeniable that economic factors also determine the choice of them to become a Waranggana. This situation is supported by the needs of the devotees to express their passion for the art of dance and the desire to show their existence as one who are able to pay through saweran or even on other chance. This situation is, then, used by the Waranggana to perform a variety of ways to increase the popularity by beautifying themselves, including by inserting the implant to their bodies so that the devotees interested in them.

\section{REFERENCES}

Cahyono, A. (2011). Pola Pewarisan NilaiNilai Kesenian Tayub (Inheritance Pattern of Tayub Values). Harmonia: Journal of Arts Research and Education, $7(1), 18-26$.

Geertz, C. (2013). Agama Jawa: Abangan, Santri, Priyayi dalam Kebudayaan Jawa. Translated by Aswab Mahasin. Jakarta: Komunitas Bambu.

Haryono, S. (2002). Penari Tayub Sebagai Dukun dalam Ritus Bersih Desa di Jogowangsang, Purworejo Jawa Tengah. Jurnal Pengetahuan dan Penciptaan Tari. 1(1), 20-31.

Hauser, A. (1982). The Socialogy of Art. Chicago: The University of Chicago.

Herusatoto, B. (2001). Simbolisme dalam Budaya Jawa. Yogyakarta: Hanindita 
Graha Widia.

Hidajat, R. (2011). Bentuk dan Gaya Tari Remo dalam Pertunjukan Tayub di Malang. Independently funded unpublished research report. Malang: Universitas Negeri Malang.

Holt, C. (2000). Art in Indonesia: Continuities and Change. Translated by Soedarsono. Bandung: MSPI.

Indriyanto. (2011). Kebangkitan Tari Rakyat di Daerah Banyumas (The Resurgence of Folk Dances in Banyumas). Harmonia: Journal of Arts Research and Education, 2(2), 60-66.

Irianto, A. M. (2005). Tayub, antara Ritualitas dan Sensualitas, Erotika Petani Jawa Memuja Dewi. Semarang: Lengkongcilik Press.

Jazuli, M. (1994). Telaah Teoritis Seni Tari. Semarang: IKIP Semarang Press.

Jazuli, M. (2009). Popularitas Sinden. Harmonia Journal of Arts Research and Education. 9(2), 120-130.

Juwariyah, A. (2013). Perempuan Waranggana langen Tayub di Masyarakat Agraris. Lentera, Jurnal Studi Perempuan. 9(1), 1-16.

Juwariyah, A. (2012). Realitas Sosial dan Kultural Langen Tayub Nganjuk Dalam Perspektif Konstruksi Sosial Peter L.Berger dan Thomas Luckmann. Disertation. Prodi S3 Ilmu Sosial, Fakultas Ilmu Sosial dan Ilmu Politik Universitas Airlangga.

Linggasari, D. (2007). Ronggeng. Yogyakarta: Kunci Ilmu.

Merriam, A. P. (1964). The Antropology of Music. Bloomington: Northwestern University Press.

Nancy, I. C. (2000). Singing and Silences: Transformations of Power through Javanese Seduction Scenarios. American Ethnologist Journal of American Ethnologist Society, 27(3), 609-644.

Prabaningtyas, N. (2013). Pertunjukan Tayub dalam Analisis Dramaturgi (Studi Deskriptif Waranggana Tayub Di
Dusun Ngrajek, Desa Sambirejo, Kabupaten Nganjuk). (Online). 2(1). Retrieved from http://journal.unair. ac.id/article_4708_media135_category8.html. December 13, 2013.

Raffles, T. S. (2008). Sejarah Jawa. Trans- lated by Eko Prasetyaningrum. Yogyakarta: Narration.

Ratih, E. W., Malarsih \& Lestari, W. (2005). Citra Wanita Dalam Pertunjukan Kesenian Tarub (The Woman Image in The Tayub Art Performance). Harmonia: Journal of Arts Research and Education, 6(2), 142-150.

Ritzer, G. \& Douglas J. G. (2008). Teori Sosial Modern. Jakarta: Kencana.

Salim, A. (2002). Perubahan Sosial, Sketsa Teori dan refleksi Metodologi Kasus Indonesia. Yogyakarta: Tiara Wacana.

Subandi. (2003). Sendratari Langendriyan Abimayu Gugur. Harmonia: Journal of Arts Research and Education, 4(1), 20-30.

Suharji. (2011). Tayub Janggrungan Sebagai Sarana Upacara Lempokan Nyiwer Sawah. Panggung Jurnal Seni dan Budaya, 21(2), 130-139.

Suharto, B. (1999). Tayub: Pertunjukan \& Ritus Kesuburan. Bandung: Masyarakat Seni Pertunjukan Indonesia.

Suprihatin, E. W. (1997). Bentuk dan Gaya Tari Remo Malang. Bahasa dan Seni. 37(2), 131-139.

Tohari, A. (2001). Ronggeng Dukuh Paruk. Jakarta: Gramedia Pustaka Utama.

Triesnawati, P. R. (2013). Kesenian Tayub di Lingkungan Seni "Mekar Pusaka". Ringkang. 1(3), 1-23.

Informants:

Sumantri (57 years), an artist of Karawitan Tayub who has been performing this art in 1950s.

Ruminingsih (60 years), a Waranggana and daughter of Tayub drummer from Jatiguwi, Malang. 